clear, though, that more than a century after Japan was opened to trade, differences in language and culture are still felt to provide be barriers to intercourse with the rest of the world.

From the inside, Japan can seem a small, homogeneous, hierarchical and conservative country far removed from the vaster flux of events occurring in the United States and Europe. The distant West often seems romantic - a feeling Japanese TV commercials have learnt to exploit with great skill.

But the West can be seen as threatening, too, with cultural and language barriers providing convenient protection for Japan. After all, will not "internationalization" mean "westernization" and risk the destruction of the form of society that has reaped such tremendous material benefits for Japan?

In public life the oscillations between the view that Japan should become part of the larger world and the view that its uniqueness must be protected seem to continue endlessly. Recent weeks have seen a sudden insistence by the Ministry of Education, Culture and Science that the national anthem be sung and the Rising Sun flag be hoisted at school ceremonies in an attempt "to strengthen national identity".

The same aims can be seen at work in proposals to set up an "International Centre for the Study of Japanese Culture" in Kyoto. When the idea was first mooted it was for an institute where foreign scholars with an interest in Japan could carry out research and have effective access to source materials. But recently Prime Minister Yasuhiro Nakasone has taken a strong interest in the centre and its stated goal has become "to explain, defend and export Japanese, cultural values to the rest of the world". The Prime Minister is quoted as saying that "Forty years have passed since the end of the war... now is the time to establish Japan's identity once again. And that is why I am calling for the creation of the centre". Among those tipped to act as advisers to the centre is Kinji Imanishi, a man often described as a uniquely Japanese thinker, but whose anti-darwinian evolutionary theories, inspired by his view of Japanese society, would not last long if subject to international attention.

Despite such pronouncements, Nakasone is most vigorous in his calls for the internationalization of Japan. But his view seems to be that strengthening Japan's identity is the only way for Japan to take an equal place in the community of nations. Paradoxically, nationalism then becomes a prerequisite of internationalism. If this were so, true exchange of ideas would become impossible, for contact with foreigners would simply be a way of reasserting Japan's "unique cultural identity".

At Tsukuba (and at universities elsewhere) many foreigners complain of the separate treatment they receive: "Foreigners are put in a box," as one lecturer put it, "where Japanese can come and get a controlled dose of internationalization." But internationalization can be something more than that. At its simplest it surely means no more than just giving foreigners equal treatment and allowing them the same role in university life as Japanese teachers. There is really nothing very difficult about it: private universities have been giving equal treatment to foreign staff for years. That the national universities were originally set up to import learning to aid Japan's modernization and that their staff have the status of civil servants should not be a barrier.

Special procedures may well be necessary to recruit foreigners, for they will not have the network of supporters usually so necessary to obtain employment. But beyond that why treat foreigners differently? Why not let the job go to the most talented person applying for it? So far, a mere four state universities have given long-term employment to just five foreigners.

Those who fear that foreigners will never understand Japanese concepts of harmony and will disrupt proceedings if allowed to serve on committees may find themselves in for a pleasant surprise. And those like Nakasone who worry about national identity can be sure that exposure to foreigners and foreign ideas will simply give further rein to the Japanese genius for absorbing the best ideas from anywhere they can be found. Nothing is more likely to kill Japaneseness than a deliberate attempt to inculcate it.

\section{Is freedom a luxury?}

The issue of tenure threatens British academic peace. But there is a new plan for change.

THE doctrine that those who work in academic institutions should be entitled to life-long tenure of their posts has become a divisive issue between academics and the rest of society, especially in financially hard-pressed countries such as Britain, where the government has embarked on a legal procedure to extinguish such right of tenure as there may be in contracts of employment issued by universitites to the members of their teaching staffs. Since the chief consequences of that procedure will be a worsening of already strained relations between the government and the universities, those concerned should be compelled to read the interesting document on the subject put out last week by the Council for Science and Society (Academic Tenure - Luxury or Necessity, $£ 2.50$, from 3-4, St Andrew's Hill, London EC4). The document has been drawn up by a committee under Sir Stephen Bragg. Properly, it points to the general misconception, especially among British politicians, about the degree to which academics are protected from misfortune by their contracts of employment; academic life is not really as secure as generally supposed. Rightly, the document also argues that the social function of academic institutions would be compromised if academics could be sacked as easily as if they were workers at, say, a building site, which would often be a recipe for suppressing even constructive unorthodoxy, but it goes on to ask that academics themselves should appreciate the difficulties that must arise when universities are forced, by financial pressures of the changing pattern of student demand, to think of closing whole departments. These days, circumstances can arise when tenure rights become threats to the survival of whole institutions.

The particular value of the document, however, is that it carries the argument a step further than most other discussions of the right of tenure, arguing that the right of academic tenure cannot be considered in isolation. In Britain, the circumstances are complicated by the way in which salaries are determined; young people joining the academic profession win the right to tenure only after a probationary period, but then are placed near the bottom of a salary ladder which assures them of annual increments (supplemented, as a consequence of national negotiations with the universities, by upward adjustments for inflation). At present, British academics may be within their rights to protest that even with these benefits, they are badly paid. The council's report, however, breaks new ground with the assertion that the right of tenure, necessary as a means of ensuring people's freedom of enquiry, should not necessarily include the right to a steadily increasing salary. Academic freedom would be safeguarded, the report says, if people at odds with their departments or institutions were assured only of some basic salary. To make such a system work without too much rancour, it would probably be necessary that the funds now dispensed as salaries should be earmarked as supplements paid for identifiable services.

This proposal, cautiously described as a "tentative solution", will not readily win converts among British academics, and will have the Association of University Teachers up in arms. But the proposal deserves a sympathetic hearing, one entirely divorced from the question of what the basic salary should be (or whether present starting salaries are too low). The side effects of a change in this direction also would include other benefits, not least (under present circumstances in Britain) the increased freedom of universities to spend resources flexibly. Properly handled, the concept that academics joining an institution are paid a basic salary, and extra only to the extent that they contribute to their institution's economic activities, could be dignifying of the academic profession and not demeaning. So, too, would be a break with the present British convention that all academics should be paid the same, however successful (or unsuccessful) their institutions may be. 